\title{
'Circuit Children': The experiences and perspectives of children engaged in migrant smuggling facilitation on the US-Mexico border
}

\author{
Gabriella Sanchez
}

\section{Abstract}

In Mexican child protection circles the term 'circuit children' has been used to designate people under the age of 18 who cross the US-Mexico border irregularly and cyclically for the purpose of smuggling drugs or irregular migrants. Young people of the border region have historically been involved in these markets. Yet their activities have become more visible in recent years in the context of increased border militarisation, and immigration and crime controls implemented by both the US and Mexican governments. Depicted in official and media discourses as forced recruits of local organised crime gangs, circuit children have increasingly been at the centre of initiatives that seek to identify and treat them as victims of trafficking. These efforts often rely on portrayals that frame them as gullible and defenceless, and their families and communities as inherently dysfunctional, dangerous and crime-prone. The structural and geopolitical conditions related to the children's participation in smuggling, however, remain unchallenged. Most troublingly, trafficking discourses tend to silence the perspectives of circuit children themselves. This paper, based on interviews and participant observation, shows how circuit children, rather than seeing themselves as victims, articulate legitimate, important claims concerning their engagement in illicit markets, reflective of the ways they navigate the complex economic, socio-political and migratory contexts of the US-Mexico border.

Keywords: migrant smuggling, circuit children, US-Mexico Border, human trafficking

Please cite this article as: G Sanchez, "Circuit Children": The experiences and perspectives of children engaged in migrant smuggling facilitation on the USMexico border', Anti-Trafficking Review, issue 11, 2018, pp. 103-119, www.antitraffickingreview.org

This is an open-access article distributed under the terms of the Creative Commons Attribution License (CC-BY). Under the CC-BY license, the public is free to share, adapt, and make commercial use of the work. Users must always give proper attribution to the authors and the Anti-Trafficking Review. 


\section{Introduction}

Migrant smugglers — typically portrayed as foreign criminals who have hijacked borders worldwide_-are practically intrinsic to contemporary discourses on migration management and control. Smugglers are frequently depicted in media, academic and political narratives as adult men of colour from the global south, ${ }^{1}$ who as members of organised crime follow a complex business model to prey on the desperation and vulnerability of migrants. ${ }^{2}$

Despite the ubiquity of these messages, empirical research on the people behind migrants' journeys is scant. Researchers have dedicated significant time to study migrants' mobility experiences, which are often characterised by conflict and risk. There is, undoubtedly, abundant evidence of the abuses endured by migrants at the hands of smugglers. Smuggling is inherently perilous for it involves clandestine, criminalised activities. It concerns people facing different levels and kinds of vulnerability. ${ }^{3}$ None of smuggling's actors can effectively reach out to authorities for help when needed, and the agreements behind journeys cannot be effectively enforced.

Still, there is a growing body of research focusing on the experiences of smuggling facilitators themselves. Opposing a state-centric model dominated by security discourses, this work has sought to situate the facilitation of migration within traditional, indigenous, and community-based strategies of mobility. In other words, it has shown how ordinary mobility efforts are increasingly 'manufactured' as migrant smuggling within contemporary

1 See, for example: M Politzer and E Kassie, 'Niger: Smuggler's paradise', Huffington Post, 21 December 2016, retrieved 5 September 2018, https:// highline.huffingtonpost.com/articles/en/the-21st-century-gold-rush-refugees/\#/ niger; N Sobecki, 'My Smuggler, My Savior', Foreign Policy, 4 October 2017, http:// europeslamsitsgates.foreignpolicy.com/my-smuggler-my-savior-portraits-nigerafrica-europe-EU-smuggling-migration; J Holman, 'Portrait of a People Smuggler', Al Jazeera, 25 January 2016, https://www.aljazeera.com/indepth/features/2015/ 12/portrait-people-smuggler-151231125324569.html.

2 Europol-INTERPOL, Migrant Smuggling Networks in the EU: Joint Europol-INTERPOL report, Brussels, 2016.

3 W Vogt, 'Stuck in the Middle with You: The intimate labours of mobility and smuggling along Mexico's migrant route', Geopolitics, vol. 21, issue 2, 2016, pp. 366386; J Hagan, Migration Miracle: Faith, hope and meaning on the undocumented journey, Harvard University Press, Massachusetts, 2012. 
migration regimes. ${ }^{4}$ This research has also challenged the claim that migrant smuggling is generally controlled by transnationally organised crime syndicates, arguing that such narratives, at a minimum, are incomplete. Scholars have shown empirically that ordinary people-from indigenous men and women to residents along migrant trails, and from current and former migrants to elderly and at-risk adults_ - play different roles in the facilitation of migrants' journeys, operating independently and/or within personal networks, and seeking to supplement limited incomes, lacking criminal intentions or ties. ${ }^{5}$

Researchers have also identified children ${ }^{6}$ as part of smuggling processes. Children pilot the boats in which migrants travel, serve as guides and decoys, and often recruit additional children to smuggle other migrants. ${ }^{7}$ Some perform these tasks in exchange for wages or in-kind compensation, while others do so to work off their own smuggling fees as part of personal mobility strategies. ${ }^{8}$ Children's experiences in smuggling are also different from those of their adult counterparts; they face specific risks, as they often lack the social or financial capital and/or standing of adults, and their physical and emotional wellbeing

4 J Brachet, 'Manufacturing Smugglers: From Irregular to Clandestine Mobility in the Sahara', Annals of the American Academy of Political and Social Science, vol. 676, issue 1, 2018, pp. 16-35; V Stone-Cadena and S Alvarez-Velasco, 'Historicizing Mobility: Coyoterismo in the Indigenous Ecuadorian migration industry', Annals of the American Academy of Political and Social Science, vol. 676, issue 1, 2018, pp. 194-211.

5 S Zhang, Chinese Human Smuggling Organizations: Families, social networks and cultural imperatives, Stanford University Press, 2008; S Izcara Palacios, 'Coyotaje and drugs: Two different businesses', Bulletin of Latin American Research, vol. 34, issue 3, 2015, pp. 324-339; G Sanchez and S Zhang, 'Rumors, Encounters, Collaborations, and Survival: The migrant smuggling-drug trafficking nexus in the U.S. Southwest', Annals of the American Academy of Political and Social Science, vol. 676, issue 1, 2018, pp. 135-151; G Sanchez, Human Smuggling and Border Crossings, Routledge, London, 2016.

6 The term 'children' in this paper refers to anyone below the age of 18.

7 See: W Palmer and A Missbach, 'Trafficking within Migrant Smuggling Operations: Are underage transporters "victims" or "perpetrators"?', Asian and Pacific Migration Journal, vol. 26, issue 3, 2017, pp. 287-307; G Sanchez, B Navarrete, F Loera and C Zavala, Neither Criminals nor Illegals: children and adolescents in the migrant smuggling market on the US-Mexico Border, Derechos Humanos Integrales en Acci n (DHIA) and University of Texas El Paso, 2017, available at http://hdl.handle.net/1814/ 50984.

8 IOM, Egyptian Unaccompanied Migrant Children: A case study on irregular migration, IOM Egypt Office, 2017. 
can be compromised more easily. ${ }^{9}$ As a result, they are an easier target of exploitation and abuse. ${ }^{10}$ Yet our knowledge of their experiences in smuggling remains limited as well.

Relying on ethnographic work conducted with children who participate in smuggling, this paper's objective is to bring into the conversation their perspectives and experiences. Known in Mexican child protection circles as 'circuit children' they are people under the age of 18 who cross the US-Mexico border irregularly and cyclically for the purpose of smuggling drugs or irregular migrants.

Young people have historically been involved in these markets along the USMexico border. Yet their activities have become more visible in recent years in the context of increased border militarisation, and immigration and crime controls implemented by both the US and Mexican governments. Depicted in official and media discourses as forced recruits of local organised crime gangs, ${ }^{11}$ circuit children have increasingly been at the centre of initiatives identifying and treating them as victims of trafficking. These efforts often rely on portrayals that frame them as gullible and defenceless, and their families and communities as inherently dysfunctional, dangerous and crime-prone. The structural and geopolitical dynamics they face, however, remain unchallenged. Most troublingly, the focus on trafficking has silenced the perspectives of the children themselves, who far from seeing themselves as victims, articulate legitimate, important claims concerning their participation in illicit markets which reflect the ways they navigate the complex economic, socio-political and migratory contexts of the border.

9 L Heidbrink, Migrant Youth, Transnational Families and the State: Care and contested interests, University of Pennsylvania, Philadelphia, 2014.

10 UNICEF, IOM, UNHCR, Eurostat and OECD, A Call to Action: Protecting children on the move starts with better data, UNICEF, New York, 2018.

11 See: L Melesio and J Holman, 'Mexico cartels recruit children to smuggle people to US', Al Jaz̧eera, 30 October 2017, https://www.aljazeera.com/news/2017/10/ mexico-cartels-recruit-children-smuggle-people-171030103553245.html; H Martinez-Prado, 'Reclutan a ninos como polleritos', El Heraldo de Mexico, 14 August 2018, https://heraldodemexico.com.mx/estados/reclutan-a-ninos-comopolleritos/. 


\section{What is Child Trafficking?}

Some scholars and child protection advocates have begun to label children's participation in migrant smuggling as a form of trafficking in persons, ${ }^{12}$ defined in the UN Trafficking Protocol as:

'the recruitment, transportation, transfer, harbouring or receipt of persons, by means of the threat or use of force or other forms of coercion, of abduction, of fraud, of deception, of the abuse of power or of a position of vulnerability or of the giving or receiving of payments or benefits to achieve the consent of a person having control over another person, for the purpose of exploitation. ${ }^{13}$

The Protocol further states that, in the specific case of children, consent is irrelevant and that 'the recruitment, transportation, transfer, harbouring or receipt of a child for the purpose of exploitation shall be considered "trafficking in persons" even if this does not involve any of the means [stated above]. ${ }^{14}$

Moreover, 'the use, procuring or offering of a child for illicit activities ...' is also defined as a worst form of child labour under ILO Convention 182 and regarded as exploitative. ${ }^{15}$ In other words, according to international law, children who are recruited into smuggling, even if willingly so, are to be considered victims of trafficking.

It is imperative to provide protection to children who have fallen prey to criminal undertakings. Yet it is also fundamental to analyse the structural and ideological contexts in which such activities take place-and the justifications provided by various actors to counter them. ${ }^{16}$ In this case, the very call to designate the experiences of children in smuggling as a form of trafficking in

12 See, for example, Palmer and Missbach, 2017.

13 UN General Assembly, Protocol to Prevent, Suppress and Punish Trafficking in Persons, Especially Women and Children, Supplementing the United Nations Convention against Transnational Organized Crime, 15 November 2000, (Trafficking Protocol), Art. 3 (a). 14 Ibid., Art. 3 (c).

15 International Labour Organization, Convention concerning the Probibition and Immediate Action for the Elimination of the Worst Forms of Child Labour, 17 June 1999, Art. 3 (c).

16 A Wilson, Intimate Economies of Bangkok: Tomboys, tycoons and Avon ladies in the Global City, University of California Press, Sacramento, 2004. 
persons implies the acceptance of the state-centric notion that the facilitation of informal, clandestine mobility strategies inherently constitutes a crime. Furthermore, it relies on the argument that smuggling is the exclusive domain of organised crime - a claim that has been empirically brought into question. Most troublingly, both assertions risk leaving untouched the structural and geopolitical challenges that children engaged in smuggling encounter.

\section{The US-Mexico Border, Children and the Mexican Migrant Smuggling Market}

For generations, communities along the US-Mexico border have been construed as abject and dangerous places where crime and vice abound, ${ }^{17}$ and have endured efforts from their respective governments to 'secure' them. ${ }^{18} \mathrm{In}$ the US, strategies have involved the deployment of law enforcement and military forces, or the construction of walls and fences. ${ }^{19}$ Mexico has also relied on troops deployed to its border cities and towns as part of a national security strategy against crime. The securitisation of the border has all along relied on the hyper-surveillance of historically marginalised and often isolated border communities, ${ }^{20}$ coincidentally situated in privileged locations for contraband activities - a common if highly criminalised form of informal labour on the borderlands. ${ }^{21}$

17 R Dorantes, 'Homeland Secretary Nielsen said border is becoming more dangerous', KSWT 13, 18 April 2018, retrieved 8 September 2018, https://www.kyma.com/ news/homeland-secretary-nielsen-said-border-is-becoming-more-dangerous / 731515619; J A DelReal, 'Donald Trump announces presidential bid', Washington Post, 16 June 2015, https://www.washingtonpost.com/news/post-politics/wp/ 2015/06/16/donald-trump-to-announce-his-presidential-plans-today/ ?utm_term $=.54 \mathrm{a} 6527737 \mathrm{ea}$.

18 See, for example: US Department of Homeland Security (US DHS), 'We Must Secure the Border and Build the Wall to Make America Safe Again', Press release, 15 February 2018, https://www.dhs.gov/news/2018/02/15/we-must-secure-borderand-build-wall-make-america-safe-again.

19 P Andreas, Border Games: Policing the US-Mexico divide, Cornell University Press, New York, 2009; J Nevins, Operation Gatekeeper and Beyond: The war on "illegals" and the remaking of the US-Mexico Boundary, Routledge, New York, 2010.

20 G Núñez and J Heyman, 'Entrapment Processes and Immigrant Communities in a Time of Heightened Border Vigilance', Human Organization, vol. 66, no. 4, 2007, pp. 354-365.

21 S Guerra, 'La Chota y los Mafiosos: Mexican American casualties of the border drug war', Latino Studies, vol. 13, issue 2, 2015, pp. 227-244; Sanchez, 2016. 
Ciudad Juárez, located on the Mexican side of the border, is one of these communities. It has been repeatedly labelled as 'the most violent city in the world', partly due to drug-related crime and the state's responses thereto, and patterns of gender-based violence that have led to high rates of femicide, among other crimes. ${ }^{22}$ None of these problems, however, have emerged in a vacuum. Following US Prohibition, and as a result of its immediate proximity to the US, Juárez became a destination for Americans traveling to Mexico to obtain illicit substances whose consumption had been banned in the US. ${ }^{23}$ The city's dependency on the US' consumption of goods and services translated into an economy of limited employment and educational opportunities for its own residents. While the arrival of manufacturing plants or maquiladoras in the 1970s brought thousands of jobs into the city, urbanisation levels remained low. ${ }^{24}$ Incoming residents, including large numbers of women attracted by better paying employment opportunities in the maquila, often settled in remote areas of the city, where access to basic services, including water, sewage, public transportation, emergency care or law enforcement was scant. ${ }^{25}$ Such residential conditions have largely remained unchanged, with most factory employees still living in the periphery of the city, often under precarious circumstances. Sidelined by the urban economy, the residents of Ju rez's periphery often rely on informal labour as a strategy to supplement limited earnings. ${ }^{26}$ Further, the proximity to the border has led many to become involved in illicit and/or

22 See, for example: S Quinones, 'Once the world's most dangerous city, Juarez returns to life', National Geographic Magazine, June 2016; K Romero, 'The dangerous ghost town even POLICE don't dare to enter: Welcome to Mexico's murder valley', The Express, 1 January 2016, retrieved 14 September 2018, https://www.express.co.uk/ travel/articles/630733/the-dangerous-ghost-town-mexico-death-valley-juarezpictures; M von Rohr, 'The most violent city on earth: Ciudad Juarez takes on the drug cartels, Spiegel Online, 23 September 2009, http:/ /www.spiegel.de/international/ world/the-most-violent-city-on-earth-ciudad-juarez-takes-on-the-drug-cartels-a650553.html.

23 Many historians claim the current landscape of drug trafficking in Mexico, and of Juárez in particular can be traced to the US Prohibition, when the city emerged as the main supplier of alcohol for US consumption. The mechanisms to supply and smuggle alcohol were eventually adapted to other illicit drugs. See: H Campbell, Drug War Zone: Frontline dispatches from the street of El Paso and Juarez, University of Texas Press, Austin, 2009.

24 GC Valdez-Gardea, 'Current Trends in Mexican Migration', Journal of the Southwest, vol. 51, no. 4, 2009, pp. 563-583.

25 Núñez and Heyman.

26 Guerra. 
criminalised activities for income generating purposes, ${ }^{27}$ including migrant smuggling.

\section{Methods}

This paper documents the experiences of children from the periphery of Ciudad Juárez who were identified by Mexican authorities as circuit children as a result of their involvement in the smuggling of migrants into the US city of El Paso, Texas. It is based on data collected between 2015 and 2018, and involves 18 interviews with children aged 14 to 17 as well as ethnographic observations carried out through personal interactions with the children, their friends, family members and a team of social workers who assisted them in Ciudad Juárez. These interactions involved attending parties, community gatherings, visits to museums and parks, focus groups and debriefing exercises intended for the children to reflect on their border crossing experiences. Sixteen of the respondents were boys; two were girls. Sixteen interviews took place in person, and two over the phone. All interactions took place in Spanish.

The children were recruited for interviewing following their referral to a local non-profit organisation, which administered a state-funded programme based in Ciudad Juárez targeting circuit children. The programme aimed to reduce the likelihood of children to engage in risk-prone behaviour-including migrant smuggling - through the provision of educational, employment, recreational and therapeutic services. The 18 children were selected upon recommendations from the social workers who worked with them, based on their level of participation in the programme. Parental and/or guardian consent was obtained prior to any research-focused interactions with the children, who also provided their own consent. No deception was used.

The children were informed that their responses would be used to better understand the lives of young people like themselves living on the border, and to devise potential ways to improve their quality of life. In line with the research strategies used by Zhang, Sanchez and Achilli ${ }^{28}$ in their work with adults involved in migrant smuggling, the children were not asked about

27 Campbell; Sanchez.

28 Sanchez and Zhang. See also: L Achilli, 'The Good Smuggler: The ethics and morals of human smuggling among Syrians', The Annals of the American Academy of Political and Social Science, vol. 676, issue 1, 2018, pp. 77-96. 
smuggling in and of itself. Instead, the questions focused on their social lives as border residents, and on the implications that their experiences crossing the border had had on themselves and their families. The children were not asked questions that would incriminate or connect them to specific people or practices. Any data that could trace statements to specific children, their families or their places of residence has been removed to further preserve the respondents' anonymity.

\section{Smuggling as an Economic Activity}

The children perceived the facilitation of border crossings as a viable and legitimate occupational activity. Helping migrants enter the US allowed the children to profit from their privileged knowledge of local conditions. A 15year-old described how he used his knowledge of a hill close to his home to attempt reaching El Paso:

'Well, of course I know the hill, we played there! I live like three blocks away from it. I knew where the good hiding places were. I just had to do what I always did. Go up the hill, hide, as us kids do! The bad thing was that the day my friends and I tried to cross it was really hot. I didn't think about that. And after two hours of walking I was like no way, I can't do this. And we just sat by a little shrine and waited. Immigration came by really soon. Another time a lady came by, I was by the dam gates. She asked me if I knew how to get across and I said yes, that I could guide her, but la migra ${ }^{29}$ caught us before we were able to cross.'

While media often describe children engaged in smuggling as passive or manipulated subjects at the mercy of criminal groups, the boys and girls in this study conceptualised their involvement in criminalised activities as the result of conscious and personal attempts to reduce the financial and emotional precarity faced by themselves and their families. A 14-year-old narrated how he took the job of a lookout after he dropped out of school at age 11:

'I had stopped going to school, I used to get bored there. And so my friend invited me to be a lookout for the times when the older guys crossed people. I had nothing else to do, and my friend and I would

29 US immigration agents. 
just go, sit by the place where we usually played and help out. I thought, at least doing this I am making some money, right? So I stayed and worked with them for a while.'

These perceptions were at times shared by the children's relatives, who may also benefit from the earnings. The older sister of a teenage boy who worked as a smuggling guide described her brother's rationale to join the market:

'My parents died and I was already married so I brought my little brother and sister to live with us. But my brother realised pretty quickly that we were struggling [financially]; he was not dumb. My husband did not earn much and I could not go get a job because there was nobody who could help me watch my children. One day my brother came home and gave me money and said, "here, so that you can buy us food." I got scared because he was only 13 and I wondered, where [did he get] all this money from? And so I asked him, and he wouldn't tell me. "What do you care", he said, "I am just tired of seeing how much you guys struggle. Just take it." I didn't like [that he was involved in smuggling], but I was like, what else is there for him to do? [My husband and I] would sit down with him, tell him we wanted him to go back to school. But he also knew we couldn't afford that, and so he would just go work with this other boy his age.'

None of the children described their entrance into smuggling as the result of pressure, coercion, or recruitment from organised crime, as press and official reports often claim. Instead, most were invited to join a job (un jale) by trusted people like friends or family members, or by older peers who were already participating in the activities. A teenage boy who worked as a guide explained:

'I was with two of my friends, just there doing nothing, and this guy we know came by and said he was looking for three people to cross people and we said, sure why not? He asked us to come by later on and we did and that was how we got into it.'

The children benefitted financially from their activities, although their compensation varied greatly and assignments were infrequent. ${ }^{30}$ Moreover,

30 Compensation promises or estimates are not a reliable indicator of smuggling earnings. While on occasion, successful outcomes following an act of smuggling may generate several hundred dollars for a child, income is never guaranteed, constant nor fixed, and many times promises of payment go unfulfilled. 
income generation was only one of several aspects that they considered important or relevant to their experience. For example, working was also seen as a path towards social recognition and acceptance. On occasion, their earnings allowed them to assume roles otherwise restricted to adults — and in particular, to men. This is of special relevance since most children involved in the market are boys, and many come from single-parent households. A teenage boy who worked as a guide explained how, by the age of 12 , his involvement in smuggling had made him his family's main provider-a role he had understood as traditionally reserved to adult men. Working allowed him to fulfil 'gendered social hierarchies and expectations, but also [to] reproduce and reinforce them': ${ }^{31}$

'We were able to buy pizza for everyone. You know, the one with ham and pineapple-that was my favourite. I was only 12 but I knew [then] what it meant to be able to buy that by myself, for my little siblings. Se siente bonito [it feels nice] to be able to buy shoes and clothes for everyone, to tell my mom not to worry, that I can take care of things. I also realised that my little siblings looked up to me as a father; they would call me papá. And my boss liked me because I was a good worker. That also made me feel good, that I could be of service, that what I did meant something.'

During interviews, several children noted that they spent their earnings on new clothes, cell phones and eating out. Many others proudly spoke about how they envisioned their employment as a way to move out of poverty. Some said that they shared their earnings with their mothers, or bought presents for their younger siblings. In sum, all children indicated that the economic activities allowed them to pursue personal, social and economic projects that symbolically raised their status.

\section{Smuggling as Emotional Labour}

While depicted in the media as inherently criminal and violent communities, the interviewed children described their working-class neighbourhoods in the periphery of Ciudad Juárez as the places where

31 J Miller and K Carbone-Lopez, 'Beyond "Doing Gender": Incorporating race, class, place and life transitions into feminist drug research', Substance Use and Misuse, vol. 50, no. 6, 2015, pp. 693-707. 
they felt welcome and safe. Many preferred to stay in their communities rather than going into other parts of the city. In fact, several reported that they knew few other places in Juárez. Some described how at times, when going to different neighbourhoods, or public spaces like malls and markets, they would be followed by security guards, or even be asked to leave by staff or other adults.

The children enjoyed describing the ways in which they spent afternoons together among friends, visiting relatives or meeting people. The neighbourhood was an important place for recreation and community building, and most importantly a safe space. A 17 -year-old girl who had worked as a lookout noted when shown pictures of her neighbourhood:

'When I see pictures of my colonia [neighbourhood] it feels nice. I think, see? 'That's where I'm from. [Pointing at the picture] There is my aunt's house, my mom's house, the street where I play with my friends. There are poor people, and yes, there are also bad people. But it is my neighbourhood, you see. We get together, party together, go to school together. I like my neighbourhood and I miss it when I'm gone. I really do.'

This attachment to their own families and community also led children to empathise with the migrants whose journeys they facilitated. A female teenager who had worked as a decoy explained:

'It is very sad that you can't be with your family because of what happens at the border. I always felt bad about the people we crossed. Why? Because we are poor but we have always been together. If it is not my mom, the one who is caring for my boy and my little siblings (...) is me, so I understand that it is only natural that people want to be with their families. I believe there is nothing wrong with [migrants] wanting that too, and if we can help them, even better. It felt good dropping people off and watching them reunite with their families; that always made me cry. But I was also worried of what could happen to my family if I got caught, and so I stopped [working as a decoy]; I didn't want to be separated from them.'

Further, empathy with migrants, underpinned by family values and traditional role expectations, led one boy to express a preference for transporting female migrants, whom he perceived as facing specific, gendered vulnerabilities. Having worked as a driver from the age of 12 , he explained: 
'I always looked for the women at the safe houses. Don't ask me why, I just did. I guess they reminded me of my mom and my sisters. I would walk in, find them, wake them up if they were asleep and tell them, "wake up, I am here to drive you, let's go, you don't have to stay here." I had heard really bad stories of what happens to women when they cross and I didn't want anything to happen to them. And then we would drive and they would be all quiet but I will then try to put them at ease by telling jokes and they would ask me how old I was and when I told them they would laugh [because I was so young] and that would kind of break the ice. I wanted them to feel good, that they could trust me. Sometimes we would exchange numbers and they would text me when they arrived at their destination. It felt nice to be part of what they went through, that I could help.'

Similar to the girl who worked as a decoy, this teenager's testimony stands as an example of the emotional support the circuit children provided through humour, casual conversations, and attempts to generate a sense of normalcy for the migrants whom they transported.

\section{Risks and Challenges Faced by Children Engaged in Smuggling}

The children's testimonies were also packed with reminders that their participation in smuggling was far from safe. There are serious physical risks associated with an activity often performed in inaccessible and rugged corridors. It was common for the children to report injuries involving the handling of tools or equipment, or experiences of bone dislocations, fractures or bites from local fauna. A 16-year-old boy described how he had almost drowned while crossing a canal:

'One night we were working, we were not expecting it but the dam's gate was open and the current dragged me. I could not feel the bottom of the canal. The good thing is that we were working [in pairs], because my partner grabbed the collar of my shirt and pulled me out. If it hadn't been for him I think I would have died.' 
Moreover, and contrary to reports from the media and state officials, the children's testimonies indicated that the acts of violence they endured were not only related to organised crime groups. ${ }^{32}$ Instead, they often reported experiencing emotional or physical abuse at the hands of peers or family members whom they worked with. One child explained how, after indicating that he no longer wanted to engage in smuggling, he was tied and blindfolded by an older boy who then also unleashed a fighting dog on him. A few children felt pressured to remain in smuggling due to their families' financial expectations and legitimate needs. One boy opted to apply for asylum in the US after his father refused to allow him to quit his job as a guide. Some children also entered into conflict with other groups or criminal actors through their work, such as by using an off-limits route designated for drug trafficking. This, at times, exposed them to threats or intimidation. One child reported having to move temporarily to another state for this reason, for example.

While violence from friends, family members or criminal actors posed serious risks, interactions with law enforcement officers-especially those ascribed to the US Border Patrol-were consistently described as the most feared and dangerous. The children reported having endured verbal abuse, assault and beatings by law enforcement, and highlighted at least two cases where children like themselves were killed by Border Patrol agents. ${ }^{33}$ One of the respondents

32 This does not intend to suggest that violence at the hands of criminal groups is minimal or inexistent. Children reported having witnessed or heard of instances in which other circuit children (often migrant children travelling unaccompanied or from cities other than Juárez) had been severely beaten, shot or even killed for not following instructions from the adults who employed them. In this sample, threats of violence, or apprehension experiences proved enough of a deterrent to keep most children from re-attempting a border crossing.

33 The deaths of Sergio Hernandez Guereca and Jose Antonio Elena Rodriguez have generated condemnation over the US Border Patrol treatment of and interactions with young people and children of the US Mexico Border. See: J Burnett and M Kennedy, 'Supreme Court Sends Cross-Border shooting case back to lower court', NPR News, 26 June 2017, retrieved 12 August 2018, https:/ /www.npr.org/sections/ thetwo-way/2017/06/26/533968647/supreme-court-sends-cross-border-shootingcase-back-to-lower-court?t $=1536241861264$. At least six children have been reportedly murdered by Border Patrol agents on duty. See: S Macaraeg, 'Fatal Encounters: 97 deaths point to pattern of border agent violence across America', The Guardian, 2 May 2018, https://www.theguardian.com/us-news/2018/may/ 02/ fatal-encounters-97-deaths-point-to-pattern-of-border-agent-violence-acrossamerica. 
described how, following his apprehension, a male agent had attempted to pull by force an earring he was wearing: 'I got mad, and I told him, just pull it, whore, and I will sue you. He left me alone after that.'

By law, children found to be involved in smuggling activities do not face criminal charges due to their age. Yet, they are invariably subjected to questioning by US authorities, with child advocates having repeatedly expressed concerns over the ways US Border Patrol agents carry out interrogations in public, in a language other than the child's, and without the presence of legal counsel or parental notification. ${ }^{34}$ Further, the tense interactions between teenagers and immigration agents sometimes lead to self-incriminatory statements, as this 17-year-old demonstrated:

'[The Immigration agent] asked me how many times I had [crossed migrants], and I said, what do you care, idiot. Twenty, thirty, forty, I don't know. And the agent wrote it down as if that was true. I was mad, I was angry. I had gotten caught. He wrote it all down and then they let me go. And then when [immigration] caught me again and sent me to court [the attorney for the state] said I had [admitted to the crime] to [USBP agents]. [Laughs]. Damn it. What was I supposed to say? I didn't know.'

\section{Analysis and Conclusion}

This paper expresses concerns about the state-centric narratives often applied in discourses on children's engagement in smuggling along the US-Mexico border, including its increasing designation as a form of human trafficking or as under the monopoly of criminal syndicates. Monolithically depicting smuggling as controlled by organised crime-and children as forcefully participating in such activities as victims of trafficking-is incomplete at best.

These perspectives are not only indicative of a lack of knowledge of smuggling dynamics; most troublingly, they fail to incorporate the children's views of their personal life projects within the structural limitations they face. In other words, such simplistic narratives exclude their voices from discussions of the conditions that lead to their marginalisation as working class youth on the US-Mexico border.

34 See: G Sanchez, B Navarrete, F Loera and C Zavala; and B Cavendish and M Cortazar, Children at the Border: The screening, protection and repatriation of unaccompanied Mexican minors, Appleseed Foundation, Washington DC, 2011. 
Research on smuggling is scant, and studies documenting the experiences of children in this context are even less common. In fact, most engagements with children's smuggling activities have been journalistic in nature, and have often referred to them as coyotitos or polleritos-diminutives of derogatory terms used colloquially in reference to adult migrant smugglers. Such coverage regularly replicates and reinforces the above state-centric narrative describing the children as desperate, submissive drug addicts, forcibly recruited by organised criminals into what is labelled as a lucrative migrant smuggling trade. ${ }^{35}$ Many law enforcement agencies, politicians and scholars on the border have relied on these increasingly common media reports and language to claim that the circuit children phenomenon has grown, and that this growth is largely due to a lack of punitive laws. ${ }^{36}$

The data presented here shows that the children perceive their engagement in smuggling as a legitimate strategy to overcome the economic, socio-political and migratory barriers faced by themselves and their communities. Furthermore, their experiences point, as Vogt argues, to 'the ways in which smuggling becomes a point of closeness and intimate exchange ${ }^{37}$ among children, the people they work with, the migrants they transport or guide, and the authorities who apprehend them.

To bring these perspectives into the discussion does not imply minimising the risks children face, including dangerous work conditions, violent interactions with peers and family members, or intimidation, criminalisation and even death at the hands of law enforcement agents. Instead, it helps to juxtapose the ways children see their experiences with the narratives ascribed to them, and in so doing allows gaining new insights into young people's lives.

35 L Melesio and J Holman; H Martinez-Prado.

36 O Hernandez-Hernandez, 'Menores de Circuito en Tamaulipas', Crónica, 17 February 2018, retrieved 14 August 2018, http://www.cronica.com.mx/notas/2018/ 1065596.html; A Guerrero, 'Informe alerta del aumento de polleritos, niños que usa el crimen para traficar migrantes', Sin Embargo, 28 April 2017, http:// www.sinembargo.mx/28-04-2017/3203832.

37 Vogt. 
The children's testimonies suggested that some risks to their lives and wellbeing were the result of external, top-down, state-centric approaches to border control. Intimidation on the part of US Border Patrol, through its reliance on aggressive questioning tactics, led frustrated and scared young people into providing self-incriminatory statements that were later used against them in courts. Fear of being caught and arrested increased the propensity to engage in risky physical activities that could lead to serious injuries. The lack of mechanisms allowing children to migrate safely and with dignity contributed to them devising their own mobility strategies.

It is pivotal to remember the hypervisibility of the US-Mexico border in migration and security discourses, and how these have translated into real, specific manifestations of securitisation, marginalisation and stigmatisation impacting its communities. Alongside simplistic explanations of complex social practices like smuggling, the unrestricted, uncritical use of terms in policy, but also in academic discourses that belittle border crossing practices and their actors through terms like wetback, coyotito or pollerito also constitutes a form of violence. These word choices reveal deeply seated ageist, classist and racist tendencies, and inscribe criminal behaviours as inherent to people. The discourse of mobility on the border has become weaponised. Let us not allow it to continue being yet another form of violence against the people of the US-Mexico border — and in particular, against its children.

Gabriella Sanchez is research fellow at the Migration Policy Centre in the European University Institute and leads the Migrant Smuggling Observatory. Her ethnographic work has primarily explored the social organisation of migrant smuggling through participatory research conducted alongside and by smuggling facilitators themselves across the Americas, the Middle East, North Africa, Australia and Europe.Email: gabriella.sanchez@eui.eu. 